Bangladesh J. Bot. 49(2): 257-263, 2020 (June)

\title{
ANTIBACTERIAL AND ANTIBIOFILM PROPERTIES OF PHLOMIS AND STACHYS SPECIES
}

\author{
Aynur AybeY* \\ Department of Biology, Faculty of Arts and Sciences, \\ Bursa Uludag University, Bursa, Turkey
}

Keywords: Antibacterial activity, Antibiofilm activity, Phlomis, Stachys

\begin{abstract}
The ethyl acetate and methanol extracts of Phlomis pungens var. pungens, P. nissolii, P. armeniaca and Stachys byzantina, S. cretica L. subsp. mersiaea and S. cretica L. subsp. Smyrnaea were evaluated for their antibacterial and antibiofilm activities. Five bacterial species were used are Bacillus subtilis, Pseudomonas aeruginosa, Shigella sonnei, Salmonella typhimurium and Yersinia enterocolitica. The ethyl acetate and methanol extracts of plant species showed good antibacterial activity against all bacterial strains. More significantly, ethylacetate and methanol extracts of all Phlomis species were found to be more effective on degredation of mature biofilm against all used bacterial strains than extracts of Stachys species. The findings of the present study highlight the promising role of Phlomis and Stachys extracts as new lead structures in the search for novel antibacterial and antibiofilm agents.
\end{abstract}

\section{Introduction}

Although traditionally regarded as environmental phenomena, bacterial biofilms are increasingly considered to play a role in many human infections (Hung and Henderson 2009). Biofilm included living bacteria are intrinsically nonreactive to the host immune response and are thousand times more resistant to antibiotics (Caraher et al. 2007). Becoming increasingly resistant to bacteria, it led to conventional antibiotic therapy inactive. Eventually, researchers have undertaken to explore alternative therapeutical agents including phage therapy (Sulakvelidze $e t$ al. 2003, Fischetti 2005) and human antimicrobial peptides (De Semet and Contreras 2005).

The whole components of the Phlomis are used in folk medicine containing flowers ( $P$. aspera, $P$. rotata), leaves ( $P$. aspera, $P$. cephalotes), seeds ( $P$. cephalotes) and roots (P. nepetaefolia). Phlomis is a great beneficial group to the finding and usage of natural curative products. According to literature, a wide range of Phlomis species throughout the world have the same manner of use qua herbal tea to heal several disorders such as diabetes, gastric ulcer, hemorrhoids, inflammation, and wounds. The antimicrobial, antidiabetic, the antinociceptive, antiulcerogenic, anti-inflammatory, antiallergic and antioxidant effects of some Phlomis species extracts were also reported (Demirci et al. 2009, Ozkan et al. 2009). During the recent years, there has been a growing interest in the information available on the compositions and pharmacological properties of new substances recognized from Phlomis species.

Stachys plants have been used in traditionally folk medicine as astringent, wound-healing, anti-diarrheal, anti-nephritic and anti-inflammatory agents in many countries over the years. Moreover, antimicrobial, antioxidant and cytotoxic activities of some Stachys species are determined (Bhattacharjee et al. 1982, Saeedi et al. 2008, Dulger and Aki 2009). According to previous studies, the extracts of Stachys species exhibited concentration depedent antibacterial activity against $K$. pneumoniae, S. aureus, E. coli, P. aeruginosa, S. sangius (Saeedi et al. 2008, Dulger and Aki 2009). Pharmacological surveys have showed that extracts or compounds of Stachys species has propound notable antibacterial, antifungal, antioxidant, anti-inflammatory and

*Author for correspondence; <aybeyaynur@gmail.com>. 
hypotensive activities (Piozzi 2011). Attributable to their diverse significant effects, future investigations should be find out on the pharmalogical advance of Stachys extracts and their contents.

Recent findings showed that natural phenolic and aromatic substances which are isolated from medicinal herbs have an antibacterial and anti-biofouling effect on biofilm formation (Jagani et al. 2009). Previously antibiofilm and antimicrobial activity of various plant extracts were reported (Quave and Smeltzer 2009). In the available literature there is not much data about the antibiofilm activity of Phlomis pungens var. pungens, P. nissolii, P. armeniaca and Stachys byzantina, S. cretica L. subsp. mersiaea, $S$. cretica L. subsp. smyrnaea. Thus in the present study, antibacterial and antibiofilm activities of the ethyl acetate and methanol extracts of two plant species, Phlomis and Stachys which have been used as medicinal plants over the many years were investigated.

\section{Materials and Methods}

Phlomis armeniaca, $P$. nissolii and $P$. pungens var. pungens were collected from Kemerkaya town, Bolvadin-Afyonkarahisar-Turkey on June, 2013, Cumra-Bozkır highway, Konya-Turkey on July, 2013 and Karagöl-Cubuk, Ankara-Turkey on July, 2013, respectively. Stachys byzantina, S. cretica L. subsp. mersiaea and $S$. cretica L. subsp. smyrnaea were also collected from Kemerkaya town, Bolvadin-Afyonkarahisar-Turkey on June, 2013, Keçiborlu-Aydoğmuş highway, IspartaTurkey on June, 2014 and Isparta-Bucak-Turkey on June, 2014, respectively. All plants were obtained by Dr. Basak Gokce, Department of Pharmacy, Suleyman Demirel University.

The voucher specimen was deposited at the Herbarium in Mugla S1tk1 Kocman University, Mugla-Turkey. Taxonomic identification was confirmed by the senior taxonomist Dr. Olcay Ceylan, in Department of Biology, Mugla Sttk1 Kocman University.

Air-dried samples ( $30 \mathrm{~g}$ ) of the aerial parts (leaves) of plant species were extracted by using a Soxhlet extractor for $5 \mathrm{hrs}$ with $250 \mathrm{ml}$ of ethyl acetate and methanol. Ethyl acetate and methanol were then removed by rotary evaporator. All extracts were stored at $4^{\circ} \mathrm{C}$ until using for assays. Ethyl acetate and methanol extracts were dissolved in $20 \%$ of dimethyl sulfoxide (DMSO, CarloErba, Milan, Italy), and sterile filtered $\left(0.2 \mathrm{~mm}\right.$; nylon filter) and stored in sterile vials at $-20^{\circ} \mathrm{C}$ prior to use for antibacterial and antibiofilm assays. All experiments were carried out Department of Biology, Bursa Uudag University.

The following bacteria were used: Bacillus subtilis ATCC6633, Pseudomonas aeruginosa ATCC35032, Shigella sonnei ATCC25931, Salmonella typhimurium ATCC14028 and Yersinia enterocolitica ATCC9610. Bacterial species were obtained from the Department of Microbiology, Faculty of Medicine, Uludag University. For antibacterial assay, a single colony in Luria- Bertani (LB) agar plates of all strains was transferred to Muller Hinton broth (MHB) and then incubated at $37^{\circ} \mathrm{C}$ for $24 \mathrm{hrs}$. After incubation it was adjusted to a concentration of $1 \times 10^{6}$ colony forming units per $\mathrm{ml}(\mathrm{CFU} / \mathrm{ml})$ to add Muller Hinton agar (MHA). For antibiofilm assay, all the bacterial strains were cultured overnight at $37^{\circ} \mathrm{C}$ in $\mathrm{LB}$ medium.

Agar well diffusion assay was used to determine the antibacterial activity of plant extracts (Cheesbrough 2006). MHA plates that have been checked for sterility were seeded with $100 \mu 1$ of an overnight broth culture of each bacterial isolate in sterile Petri dishes. The seeded plates were allowed to set after a uniform distribution of the bacterial isolate following slow rotation of the Petri dishes. A sterile stainless steel cork borer was used to cut $6 \mathrm{~mm}$ diameter of wells on the agar. The wells were filled with $100 \mu \mathrm{l}$ of $5 \mathrm{mg} / \mathrm{ml}$ stock solutions of each extracts for Phlomis and Stachys species. One of the wells in each MHA plate was filled with 20\% of DMSO as a control. The plates were then allowed to stand for $1 \mathrm{hr}$ at room temperature to allow proper 
diffusion of the extracts to occur. All the plates were incubated at $37^{\circ} \mathrm{C}$ for $24 \mathrm{hrs}$ and observed for zones of inhibition. Diameters of zones were measured in millimeter $(\mathrm{mm})$ and recorded.

The microplate method of Eloff (1988) was used to determine the MIC values for ethyl acetate and methanol extracts of Phlomis and Stachys species. Ten $\mathrm{mg} / \mathrm{ml}$ stock solutions were prepared for each extract which was later transferred to 96-well microtiter plate (MTP) (SigmaAldrich, St. Louis, MO, USA) in $100 \mu \mathrm{l}$ aliquots. Prepared bacterial suspensions were pipetted into each well in an equal volume. Media containing bacterial suspensions - $20 \%$ of DMSO were served as positive growth control. The microplates were incubated at $37^{\circ} \mathrm{C}$ for $24 \mathrm{hrs}$ and absorbance values at $600 \mathrm{~nm}$ were read spectrophotometrically. MICs were recorded as the lowest concentrations of extracts. Experiments were performed in triplicate.

The effect of $2 \times$ MIC of Phlomis and Stachys ethyl acetate and methanol extracts on the biofilm formation was determined by quantifying the biofilm biomass through microtiter plate (MTP) assay (Nithya et al. 2010). Briefly, to test effects of plant extracts on biofilm formation, $100 \mu \mathrm{l}$ of $2 \times$ MIC of Phlomis and Stachys extracts were added to wells prior to bacteria inoculation. Overnight cultures of bacterial strains were adjusted to $1 \times 10^{6} \mathrm{CFU} / \mathrm{ml}$ and then 100 $\mu \mathrm{l}$ of inocula were added into MTP contained medium. MTPs were incubated in $37^{\circ} \mathrm{C}$ for $24 \mathrm{hrs}$. After incubation, MTPs were emptied by removing the media along with free-floating planktonic cells and the wells were gently rinsed twice with sterile water. The surface-attached cells were stained with $0.1 \%$ crystal violet solution. After $15 \mathrm{~min}$, crystal violet solution was discarded completely and wells were filled with $95 \%$ ethanol to solubilize crystal violet from the stained cells. The biofilm biomass was then quantified by measuring the absorbance at OD $590 \mathrm{~nm}$ using a UV-visible spectrophotometer. Experiment was repeated at three times and results were expressed average of three values.

\section{Results and Discussion}

Antibacterial activities of ethyl acetate and methanol extracts of three Phlomis and Stachys species are illustrated in Table 1a, b. From the results it can be seen that the these extracts were resulted in variable zones of inhibition $(10-26 \mathrm{~mm})$ for all bacterial strains used. DMSO as a control did not show antibacterial activity. In general, ethyl acetate and methanol extracts of six plant species have good antibacterial activity. Among bacterial strains, all bacteria were found to be more sensitive to ethyl acetate and methanol extracts of $P$. nissolii and $S$. cretica L. subsp. smyrnaea than other Phlomis and Stachys species. The largest inhibition zones were found in ethyl acetate extract of $P$. nissolii against $P$. aeruginosa $(26 \mathrm{~mm})$ and in methanol extract of $P$. armeniaca against $P$. aeruginosa $(20 \mathrm{~mm})$. In a previous study, the highest growth inhibition zones of $P$. armeniaca chloroform extract were observed against the medically important pathogens such as $S$. aureus ATCC 25923 and S. aureus Cowan $1(32 \mathrm{~mm})$, L. monocytogenes (29 $\mathrm{mm})$, B. cereus $(34 \mathrm{~mm})$ and $B$. subtilis $(33 \mathrm{~mm})$. P. pungens var. pungens $(9 \mathrm{~mm}$ for C. albicans and $8 \mathrm{~mm}$ for $C$. tropicalis) demostrated anticandidal activity. But these plants did not show antibacterial effect on $P$. aeruginosa (Dogan et al. 2010). On the contrary of these results, we reported that ethyl acetate and methanol extracts of $P$. armeniaca and $P$. pungens var. pungens showed good antibacterial activity against not only $P$. aeruginosa $(10$ and $20 \mathrm{~mm})$ but also $B$. subtilis (12 and $15 \mathrm{~mm}), S$. sonnei (Not active and $16 \mathrm{~mm}$ ), S. typhimurium (14 and $17 \mathrm{~mm}$ ) and $Y$. enterocolitica (11 and $19 \mathrm{~mm}$ ) (Table 1). In addition, ethyl acetate extract of $P$. pungens var. pungens was found more effective than methanol extract.

The two extracts of Phlomis and Stachys species used showing considerably antibacterial activity for each bacterial strains were selected to determine MICs. The MICs of extracts were determined ranging from 0.312 to $2.5 \mathrm{mg} / \mathrm{ml}$ (Table 1). On the contrary the present results MICs 
of methanol extract of $P$. pungens were determined as $50-100 \mathrm{mg} / \mathrm{ml}$ against $K$. pneumoniae ATCC 4352, P. aeroginosa ATCC 27853, B. subtilis ATCC 6633, S. aureus ATCC 29213,

Table 1. Antibacterial properties of ethylacetate (a) and methanol (b) extracts of Phlomis and Stachys species against tested bacteria.

\begin{tabular}{|c|c|c|c|c|c|c|}
\hline \multirow{3}{*}{$\begin{array}{l}\begin{array}{l}\text { Bacterial } \\
\text { species }\end{array} \\
\text { B. subtilis }\end{array}$} & \multicolumn{4}{|c|}{ (a) } & \multirow{2}{*}{\multicolumn{2}{|c|}{$\begin{array}{c}\text { Zones of } \\
\text { inhibition }(\mathrm{mm})\end{array}$}} \\
\hline & \multicolumn{2}{|c|}{$\begin{array}{c}\text { Ethyl acetate extracts } \\
\text { of plants }\end{array}$} & \multicolumn{2}{|c|}{$\begin{array}{c}\mathrm{MIC} \\
(\mathrm{mg} / \mathrm{ml})\end{array}$} & & \\
\hline & 1 & $\mathrm{a}$ & 0.625 & 1.25 & 18 & 12 \\
\hline & 2 & $\mathrm{~b}$ & 0.625 & 0.625 & 11 & 12 \\
\hline & 3 & $\mathrm{c}$ & 0.312 & 0.625 & 16 & 19 \\
\hline \multirow[t]{3}{*}{ P. aeruginosa } & 1 & $\mathrm{a}$ & 1.25 & 0.625 & 19 & 17 \\
\hline & 2 & $\mathrm{~b}$ & 1.25 & 0.312 & 11 & 10 \\
\hline & 3 & $\mathrm{c}$ & 0.625 & 0.312 & 16 & 26 \\
\hline \multirow[t]{3}{*}{ S. sonnei } & 1 & a & 0.312 & 0.312 & 16 & 10 \\
\hline & 2 & $\mathrm{~b}$ & 0.625 & 0.625 & 11 & NA \\
\hline & 3 & $\mathrm{c}$ & 0.625 & 0.625 & 17 & 21 \\
\hline \multirow[t]{3}{*}{ S. typhimurium } & 1 & $\mathrm{a}$ & 1.25 & 1.25 & 25 & 17 \\
\hline & 2 & $\mathrm{~b}$ & 1.25 & 1.25 & 13 & 14 \\
\hline & 3 & $\mathrm{c}$ & 0.625 & 1.25 & 19 & 21 \\
\hline \multirow[t]{3}{*}{$Y$. enterocolitica } & 1 & $\mathrm{a}$ & 0.625 & 2.5 & 22 & 19 \\
\hline & 2 & $\mathrm{~b}$ & 1.25 & 2.5 & 17 & 11 \\
\hline & 3 & $\mathrm{c}$ & 1.25 & 1.25 & 22 & 20 \\
\hline \multicolumn{7}{|c|}{ (b) } \\
\hline $\begin{array}{l}\text { Bacterial } \\
\text { species }\end{array}$ & \multicolumn{2}{|c|}{$\begin{array}{l}\text { Methanol extracts of } \\
\text { plants }\end{array}$} & \multicolumn{2}{|c|}{$\begin{array}{c}\mathrm{MIC} \\
(\mathrm{mg} / \mathrm{ml})\end{array}$} & \multicolumn{2}{|c|}{$\begin{array}{c}\text { Zones of } \\
\text { inhibition }(\mathrm{mm})\end{array}$} \\
\hline \multirow[t]{3}{*}{ B. subtilis } & 1 & $\mathrm{a}$ & 1.25 & 0.625 & 17 & 12 \\
\hline & 2 & $\mathrm{~b}$ & 0.625 & 0.625 & 19 & 15 \\
\hline & 3 & $\mathrm{c}$ & 1.25 & 1.25 & 21 & 14 \\
\hline \multirow[t]{3}{*}{ P. aeruginosa } & 1 & $\mathrm{a}$ & 2.5 & 1.25 & 19 & 10 \\
\hline & 2 & $\mathrm{~b}$ & 1.25 & 0.625 & 15 & 20 \\
\hline & 3 & $\mathrm{c}$ & 1.25 & 0.625 & 21 & 10 \\
\hline \multirow[t]{3}{*}{ S. sonnei } & 1 & $\mathrm{a}$ & 0.625 & 0.312 & 20 & NA \\
\hline & 2 & $\mathrm{~b}$ & 0.625 & 0.312 & 19 & 16 \\
\hline & 3 & $\mathrm{c}$ & 1.25 & 0.625 & 27 & 10 \\
\hline \multirow[t]{3}{*}{ S. typhimurium } & 1 & $\mathrm{a}$ & 2.5 & 1.25 & 33 & 12 \\
\hline & 2 & $\mathrm{~b}$ & 1.25 & 1.25 & 17 & 17 \\
\hline & 3 & $\mathrm{c}$ & 2.5 & 0.625 & 22 & 18 \\
\hline \multirow[t]{3}{*}{ Y. enterocolitica } & 1 & $\mathrm{a}$ & 2.5 & 1.25 & 19 & 10 \\
\hline & 2 & $\mathrm{~b}$ & 1.25 & 1.25 & 17 & 19 \\
\hline & 3 & $\mathrm{c}$ & 1.25 & 2.5 & 24 & 11 \\
\hline
\end{tabular}

1 - S. cretica subsp. smyrnaea, 2 - S. cretica subsp. mersiaea, 3 - S. byzantina. a - P. pungens var. pungens, $\mathrm{b}-$ P. armeniaca, c - P. nissolii.

S. epidermidis ATCC 12228, B. cereus ATCC 11778, S. enteritidis KUEN 349, P. mirabilis CCM1944 and E. coli ATCC 25922 (Ozkan et al. 2009). In a previous study, methanol extracts of Stachys byzantina, S. inflata, S. lavandulifolia and S. laxa exhibited concentration dependent 
antibacterial activity against $P$. aeruginosa, E. coli, S. aeureus, S. epidermidis and K. pneumoniae. MICs of extracts were found to range from $10-40 \mathrm{mg} / \mathrm{ml}$ against all bacteria tested (Saeedi et al. 2008). In the present study, the results revealed that the ethyl acetate and methanol extracts of Stachys and Phlomis species with lower MICs $(0.312-2.5 \mathrm{mg} / \mathrm{ml})$ and higher inhibition zones (10 - $26 \mathrm{~mm}$ ) against all bacteria tested have a strong potential as a source of antibacterial agents of nature origin.

Essential oils and plant extracts have been used in folk medicine since ancient times to cure several illneses (Nazzaro et al. 2013). The most potent antibacterial subsequents against pathogenic microrganisms come from phenolic compounds such as carvacrol, eugenol and thymol (Hyldgaard et al. 2012). Phytochemical analyses of Stachys species have confirmed the occurrence of diterpenes, phenyl ethanoid glycosides, flavanoids and saponines (Khanavi et al. 2005). In such experiments, 3-O-octanoyl (+)-catechin has been shown to cause a reduction of 1000-folds or more in viable counts of EMRSA-16 (Stapleton et al. 2004). In a previous study, amounts of (+)catechin as phenolic components of Phlomis nissolii and P. pungens var. pungens was importantly found high (Sarikurkcu et al. 2014). This would immediately appear to suggest that flavonoids such as (+)-catechin may be responsible for their antibacterial activity (Saeedi et al. 2008).

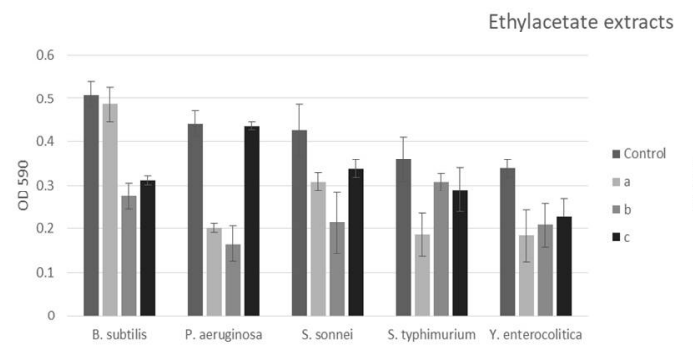

(a)

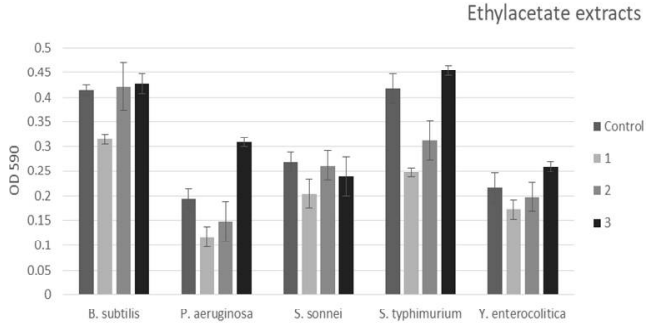

(c)

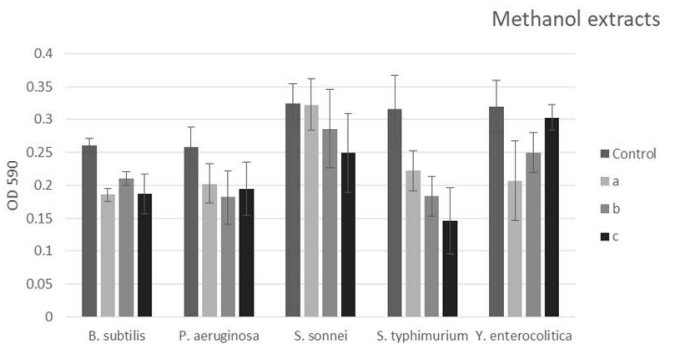

(b)

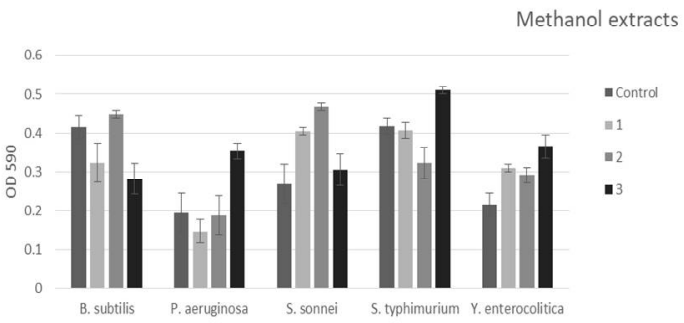

(d)

Fig. 1. Inhibitiory effects of ethyl acetate (a, c) and methanol (b, d) extracts of Phlomis and Stachys species on mature biofilm, respectively. a - P. pungens var. pungens, b - P. armeniaca, c - P. nissolii, 1. S. cretica subsp. smyrnaea, 2. S. cretica subsp. mersiaea and 3. S. byzantina.

Effects of Phlomis and Stachys extracts on mature biofilm were evaluated by crystal violet assay. Test bacterial biofilm assays showed that two extracts of all Phlomis species interfered degradation effect on only mature biofilms when compared with Stachys species, but not inhibited the starting phases of biofilm formation (datas not shown). Stachys species did not show considerable antibiofilm effect but the extracts of some Stachys species were found effective on degradation of mature biofilm (Fig. 1). In a previous study, the essential oil of Phlomis was found to be able to overcome the resistance of $S$. epidermidis at very low concentrations in both planktonic and biofilm form (Sarayreh et al. 2015). Sub-inhibitory concentrations (sub-MIC $\mathrm{Clank}_{\text {) }}$ ) 
of Phlomis brachydon essential oil to polystyrene Petri dishes containing a suspension culture of the $E$. coli strain were also able to reduce the number of individual cells adhering to the polystyrene surface (Sarayreh et al. 2015). As distinct from bacterial strains in literature and as seen in Fig. 1, ethyl acetate and methanol extracts of three Phlomis species showed more considerable antibiofilm activity against some bacterial strains than Stachys species. As biofilm is a multifactorial phenomenon, Phlomis extracts could act on the evolution of mature biofilm.

Consequently, in the present study, plants extracts inhibited the growth of bacterial strains that cause some diseases and thus plants extracts may be antibacterial agents for controlling infections. Phlomis etracts also represent the first of many steps toward to development of new antibiofilm agents. Inhibition of biofilm by Phlomis extracts provides to control the effects of pathogenic bacteria without strong selection for drug resistance. The results indicate that these Stachys and Phlomis species used in traditional medicine have antibacterial and antibiofilm activities.

\section{References}

Bhattacharjee R 1982. Stachys. In: Davis, P. H. (ed.), Flora of Turkey and the east Aegean Islands. Vol. 7. Edinb. Univ. Press, pp. 199-262.

Caraher E, Reynolds G, Murphy P, McClean S and Callaghan M 2007. Comparison of antibiotic susceptibility of Burkholderia cepacia complex organisms when grown planktonically or as biofilm in vitro. Eur. J. Clin. Microbiol. Infect. Dis. 26: 213-221.

Cheesbrough M 2006. District laboratory practice in tropical countries, Part 2, Cambridge University Press, Cambridge, UK, pp. 137-150.

De Smet K and Contreras R 2005. Human antimicrobial peptides: defensins, cathelicidins and histatins. Biotechnol. Lett. 27: 1337-1347.

Demirci B, Toyota M, Demirci F, Dadandi MY and Can Baser KH 2009. Antibacterial primaradiene diterpene from Phlomis essential oils. Compte. Rendue. Chimie. 12: 612-621.

Dogan NM, Cansaran A, Acar G and Oztekin M 2010. Antimicrobial activity of extracts of some plants from Amasya (Turkey). Adv. Biores. 1(1):87-91.

Dulger G and Aki C 2009. Antimicrobial Activity of the Leaves of Endemic Stachys pseudopinardii in Turkey. Trop. J. Pharm. Res. 8(4): 371-375.

Eloff JN 1998. Which extractant should be used for the screening and isolation of antimicrobial components from plants? J. Ethnopharmacol. 60: 1-8.

Fischetti VA 2005. Bacteriophage lytic enzymes: Novel anti-infectives. Trends Microbiol.13: 491-496

Hyldgaard M, Mygind T and Meyer RL 2012. Essential oils in food preservation: mode of action, synergies, and interactions with food matrix components. Front. Microbiol. 3:1210.3389/fmicb.2012.00012.

Høiby N, Bjarnsholt T, Givskov M, Molin S and Ciofu O 2010. Antibiotic resistance of bacterial biofilms. Int. J. Antimicrob. Agents. 35: 322-332.

Hung CS and Henderson JP 2009. Emerging concepts of biofilms in infectious diseases. Mo. Med. 106(4): 292-296.

Jagani S, Chelikani R and Kim DS 2009. Effects of phenol and natural phenolic compounds on biofilm formation by Pseudomonas aeruginosa. Biofouling 25(14): 321-324.

Khanavi M, Sharifzadeh M, Hadjiakhoondi A and Shafiee A 2005. Phytochemical investigation and antiinflammatory activity of aerial parts of Stachys byzantina C. Koch. J Ethnopharmocol. 97: 463-468.

Nazzaro F, Fratianni F, De Martino L, Coppola R and De Feo V 2013. Effect of essential oils on pathogenic bacteria. Pharmaceuticals 6: 1451-1474.

Nithya C and Pandian SK 2010. The in vitro antibiofilm activity of selected marine bacterial culture supernatants against Vibrio spp. Arch. Microbiol. 192: 843-854.

Ozkan O, Aydin H and Bagcigil AF 2009. In vitro evaluation of antimicrobial activities of Salvia verticillata and Phlomis pungens. Kafkas Univ. Vet. Fak. Derg. 15(4): 587-590. 
Piozzi F and Bruno M 2011. Diterpenoids from roots and aerial parts of the genus Stachys. Rec. Nat. Prod. 5(1): 1-11.

Saeedi M, Morteza-Semnani K, Mahdavi MR and Rahimi F 2008. Antimicribial studies on extracts of four species of Stachys. Indian J. Pharm. Sci. 70(3):403-406.

Sarayreh S, Rawashdeh A, Tarawneh I and Qudah M 2015. Phlomis brachydon essential oil against bacterial biofilm. Jordan J. Biol. Sci. 5(4): 315-318.

Sarikurkucu C, Uren MC, Tepe B, Cengiz M and Kocak MS 2014. Phenolic content, enzyme inhibitory and antioxidative activitypotentials of Phlomis nissolii and P. pungens var. pungens. Ind. Crop. Prod. 62: 333-340.

Stapleton PD, Shah S, Hamilton-Miller JMT and Taylor PW 2004. Anti Staphylococcus aureus activity and oxacillin resistance modulating capacity of 3-O-acyl-catechins. Int. J. Antimicrob. Agents 24: 374-380.

Sulakvelidze A, Alavidze Z and Morris JG Jr 2001. Bacteriophage therapy. Antimicrob. Agents Chemother. 45: 649-659.

Quave CL and Smeltzer MS 2009. Anti-biofilm activity of Marrubium vulgare L. (Lamiaceae) extract on MRSA. Planta Med. 75(4): 96.

(Manuscript received on 21 November, 2018; revised on 7 July, 2019) 